\title{
Article \\ Exploring Local Riverbank Sediment Controls on the Occurrence of Preferential Groundwater Discharge Points
}

\author{
Martin A. Briggs ${ }^{1, * \mathbb{C}}$, Kevin E. Jackson ${ }^{2} \mathbb{D}^{\text {, Fiona Liu }}{ }^{2}$, Eric M. Moore ${ }^{2}$, Alaina Bisson ${ }^{2}$ and Ashley M. Helton ${ }^{2}$ \\ 1 Earth System Processes Division, Hydrogeophysics Branch, US Geological Survey, Storrs, CT 06269, USA \\ 2 Department of Natural Resources and the Environment, Center for Environmental Sciences and Engineering, \\ University of Connecticut, Storrs, CT 06269, USA; kevin.jackson@uconn.edu (K.E.J.); \\ fiona.liu@uconn.edu (F.L.); eric.m.moore@uconn.edu (E.M.M.); alaina.bisson@uconn.edu (A.B.); \\ Ashley.Helton@uconn.edu (A.M.H.) \\ * Correspondence: mbriggs@usgs.gov
}

check for updates

Citation: Briggs, M.A.; Jackson, K.E.; Liu, F.; Moore, E.M.; Bisson, A.; Helton, A.M. Exploring Local Riverbank Sediment Controls on the Occurrence of Preferential Groundwater Discharge Points. Water 2022, 14, 11. https:// doi.org/10.3390/w14010011 Academic Editors: Carlos Duque and Donald Rosenberry

Received: 30 October 2021 Accepted: 15 December 2021 Published: 22 December 2021

Publisher's Note: MDPI stays neutral with regard to jurisdictional claims in published maps and institutional affiliations.

Copyright: (c) 2021 by the authors. Licensee MDPI, Basel, Switzerland. This article is an open access article distributed under the terms and conditions of the Creative Commons Attribution (CC BY) license (https:// creativecommons.org/licenses/by/ $4.0 /)$.

\begin{abstract}
Groundwater discharge to rivers takes many forms, including preferential groundwater discharge points (PDPs) along riverbanks that are exposed at low flows, with multi-scale impacts on aquatic habitat and water quality. The physical controls on the spatial distribution of PDPs along riverbanks are not well-defined, rendering their prediction and representation in models challenging. To investigate the local riverbank sediment controls on PDP occurrence, we tested drone-based and handheld thermal infrared to efficiently map PDP locations along two mainstem rivers. Early in the study, we found drone imaging was better suited to locating tributary and stormwater inflows, which created relatively large water surface thermal anomalies in winter, compared to PDPs that often occurred at the sub-meter scale and beneath riparian tree canopy. Therefore, we primarily used handheld thermal infrared imaging from watercraft to map PDPs and larger seepage faces along 12-km of the fifth-order Housatonic River in Massachusetts, USA and 26-km of the Farmington River in Connecticut, USA. Overall, we mapped 31 riverbank PDPs along the Housatonic reach that meanders through lower permeability soils, and 104 PDPs along the Farmington reach that cuts through sandier sediments. Riverbank soil parameters extracted at PDP locations from the Soil Survey Geographic (SSURGO) database did not differ substantially from average bank soils along either reach, although the Farmington riverbank soils were on average $5 \times$ more permeable than Housatonic riverbank soils, likely contributing to the higher observed prevalence of PDPs. Dissolved oxygen measured in discharge water at these same PDPs varied widely, but showed no relation to measured sand, clay, or organic matter content in surficial soils indicating a lack of substantial near-surface aerobic reaction. The PDP locations were investigated for the presence of secondary bank structures, and commonly co-occurred with riparian tree root masses indicating the importance of localized physical controls on the spatial distribution of riverbank PDPs.
\end{abstract}

Keywords: groundwater-surface-water interaction; sediment-water interface; heat tracing; river

\section{Introduction}

Preferential flow processes continue to be recognized as the rule rather than the exception regarding how water moves through the near surface critical zone [1-4]. Sediment structures ranging from cracks, to burrows and root cavities [5], to lenses of relatively high permeability [6], serve to focus flow through the vadose and saturated zones, impacting the transport of solutes and heat. A portion of recharge ultimately discharges to various surface water bodies through a wide range of spatially diffuse and 'preferential' mechanisms, with the latter creating unique temperature and/or chemical niches that can serve as ecosystem control points and support groundwater dependent ecosystems [7]. For example, relatively cold groundwater discharging in summer can serve as a local thermal refuge for a host of cold-water fish species [8], while relatively warm discharge in winter can enhance fish egg development [9] and promote streambed benthic organism overwintering in the arctic [10]. 
Further, as groundwater is often of differing gas and chemical composition than surface water, discharge can have a profound influence on surface water quality [11-13], including contaminants of emerging concern [14]. However, our ability to predict preferential groundwater discharge point occurrence and biogeochemical functionality along rivers remains limited due to relative lack of research focus on discrete discharge features at system-representative scales (e.g., $10 \mathrm{~s}$ of $\mathrm{km}$ ). The spatial distribution of groundwater discharge along river networks directly influences a wide range of water quality and stream habitat characteristics, including the transport of legacy contaminants from aquifer source zones to channel waters [15].

Groundwater discharge along the river corridor occurs directly through bed sediments, along riverbanks and riparian zones, and via hillslope seeps and springs [16]. In drainage systems of highly permeable near surface bedrock, topography may be a primary control on groundwater discharge pathways to rivers, while in systems with mixed and low permeability, sediments may show less direct topographic influence [17]. Riverbank discharge points are typically exposed above the waterline during summer flows, but submerged during high flow events. Based on previous work, riverbank sediment type and discharge water contact time within the near-surface reactive riverbank sediments affect net flowpath biogeochemical reactions [18], discharge temperature [19], and ultimately the water quality of the emergent groundwater. Near-surface sediment permeability can be highly variable laterally and with depth along streambeds [20], and zones of relatively high sediment and bedrock hydraulic conductivity (coefficient of permeability) can act as focused conduits for groundwater discharge at the m-scale when hydraulic gradients are toward the river [21] Compared to bed sediments, riverbanks have been less studied in the context of local permeability zonation, and in general the physical controls on the occurrence of riverbank discharges are poorly understood. In one localized study, three sediment cores collected at points of strong, preferential groundwater discharge indicated an increase in hydraulic conductivity of approximately two orders of magnitude compared to adjacent non-discharge locations [19]. Conceptually, lenses of highly permeable sediments are expected to focus lateral groundwater flowpaths from hillslopes to rivers [16], potentially controlling the occurrence of discharge, and publicly available soils data resources exist for many river systems globally. For example, the Soil Survey Geographic (SSURGO) database complies data collected by the U.S. Department of Agriculture National Cooperative Soil Survey over the course of a century, and includes attributes directly relevant to preferential groundwater discharge. As surficial soil properties are now being mapped (inferred) at unprecedented resolution using emerging machine learning methodologies (e.g., [22-24]), opportunities exist to scale up the study of sediment controls on how groundwater discharges organize along larger rivers that have more typically been avoided for groundwater/surface water exchange research using physical methods alone.

Macropore flow confounds the porous media flow paradigm, allowing the effective short circuit of high discharge through low permeability materials, such as peat [25] and clay [2]. Connected voids and cracks through sediments are often not represented in largescale groundwater flow models but can greatly enhance the migration of contaminants [26]. Macropores act as preferential conduits of riparian groundwater flow to streams if they physically connect groundwater to surface waters [5]. Discharge through macropores can exist at nested scales from $\mathrm{mm}$ to $\mathrm{cm}$-scale+ voids [27]. While macropores that convey flow have recently been found to be ubiquitous along streambanks in varied geologic terrain, and sometimes associated with living plant roots [2], their overarching control on preferential groundwater discharge processes relative to flow through porous media has not been widely assessed.

Commonly used physical methods of measuring groundwater/surface water exchange dynamics typically have limited spatial coverage, resulting in time-intensive surveys of even short reach lengths (e.g., $100 \mathrm{~s}$ of $\mathrm{m}$ ), as reviewed by [28]. Preferential upward flow through highly permeable streambed interface sediments is challenging to quantify using physical instruments, such as seepage meters [29]. For high groundwater flux rates 
(i.e., $>1.5 \mathrm{~m} /$ day), natural thermal signals show minimal vertical propagation downward into the streambed, also confounding vertical bed heat tracing methods, and potentially requiring the use of active heat pulses [30]. However, evolving heat sensing methodologies can allow for efficient and comprehensive mapping of preferential discharge points across space under appropriate field conditions. Preferential groundwater discharge tends to affect streambed and bank sediment interface temperatures during times of pronounced contrast with surface water temperature, and such thermal anomalies can be located with a range of heat tracing approaches [31]. For example, direct measurements of streambed temperature collected at a common depth across space over short periods of time (i.e., hours) can indicate zones of groundwater discharge, though spatial coverage is typically limited to approximately $20 \times 10^{3} \mathrm{~m}^{2}$ surveys [32-34]. Fiber-optic distributed temperature sensing of groundwater discharge locations can be accomplished using armored cables installed along bed interface sediments [25,35-37]. When these cables pass directly over active discharges, their distribution is mapped at high spatial resolution [38], but in mainstem rivers only a fraction of the riverbed is directly surveyed with fiber-optics, and cables are not typically deployed out of the water along streambanks.

Remotely sensed thermal infrared (IR, $8-12 \mu \mathrm{m}$ ) data can be used to evaluate the 'skin' surface temperature of water and bank features [39], and harnessed to efficiently map preferential groundwater discharge locations when surface temperature anomalies exist and are not obscured by IR reflection [40], or vegetation and debris [41]. Spatial coverage can be greatly enhanced through airborne surveys, from both occupied $[42,43]$ and unoccupied drone platforms [44]. However, substantial questions remain regarding what scale and type of preferential riverbank discharge processes may be captured using airborne data compared to high-resolution ground-based (handheld) infrared imaging. The latter has been shown to be highly effective at detailing focused discharge at the local bank scale $(1-10 \mathrm{~s}$ of $\mathrm{m})[19,27]$, but has been less-applied at the $10 \mathrm{~s}$ of $\mathrm{km}$-scale, where airborne thermal IR is more often used to map tributary confluences and large riverbank spring complexes (e.g., [17]).

For this study, we applied handheld and drone-based thermal IR sensing to map preferential groundwater discharge along the banks of two mainstem fifth order rivers draining glacial terrain. For over $40 \mathrm{~km}$ of river survey, we observed groundwater discharges to occur both as extended discharge 'faces' ranging 10 to $238 \mathrm{~m}$ in length laterally along the banks, along with more focused, high-flow preferential groundwater discharge points (PDPs) less than $10 \mathrm{~m}$ in length, and sometimes occurring at singular macropore points. The spatial distribution of more extensive bank discharge areas can be driven by a combination of riparian, hillslope, and more regional valley physical factors [16] that have been evaluated using airborne thermal IR [42]. For this study, we investigated the local riverbank sediment controls on spatially focused PDP occurrence. Our central hypothesis was that the spatial distribution of PDPs along mainstem rivers may be controlled primarily by local riverbank sediment type but also be influenced by secondary physical structures such as cracks and macropores. Our research goals for this study ranged from methodological to scientific as:

1. Assess drone vs. handheld thermal IR methods for mapping groundwater discharge occurrence along the banks of mainstem rivers;

2. Explore relationships between local bank soil properties mapped by the SSURGO database and PDP occurrence along two mainstem river reaches of differing valley geomorphology;

3. Directly measured surficial bank soil parameters at a subset of PDPs and compare to dissolved oxygen in discharge water and comparable SSURGO parameters;

4. Investigate the co-occurrence of tree roots and other physical structures with riverbank PDPs that might drive macropore flow. 


\section{Materials and Methods}

\subsection{Site Description}

We performed paired remotely sensed thermal IR and direct physical groundwater discharge surveys along the riverbanks of two fifth-order river sections in adjacent watersheds where the local hydrogeology is expected to be conducive to riverbank discharge processes (Figure 1). The meandering $12 \mathrm{~km}$ study reach of the Housatonic River drains an unconfined valley with substantial accumulations of fine glacial lake sediments. The average annual river flow in the general area of the study reach is $27.1 \mathrm{~m}^{3} / \mathrm{s}$ (USGS 01198125 stream gage near Ashley Falls, MA, [45], average flow based on yearly statistics 2008-2019). The 26-km study reach of the Farmington River drains a partially confined valley, and generally has more heterogeneous surface material, ranging from fine-grain alluvium to coarse till [46]. The average annual discharge of the Farmington River is similar to that of Housatonic gage at $32.3 \mathrm{~m}^{3}$ /s (USGS 01189995 stream gage near Tariffville, CT [45], average discharge based on yearly statistics 2008-2019).

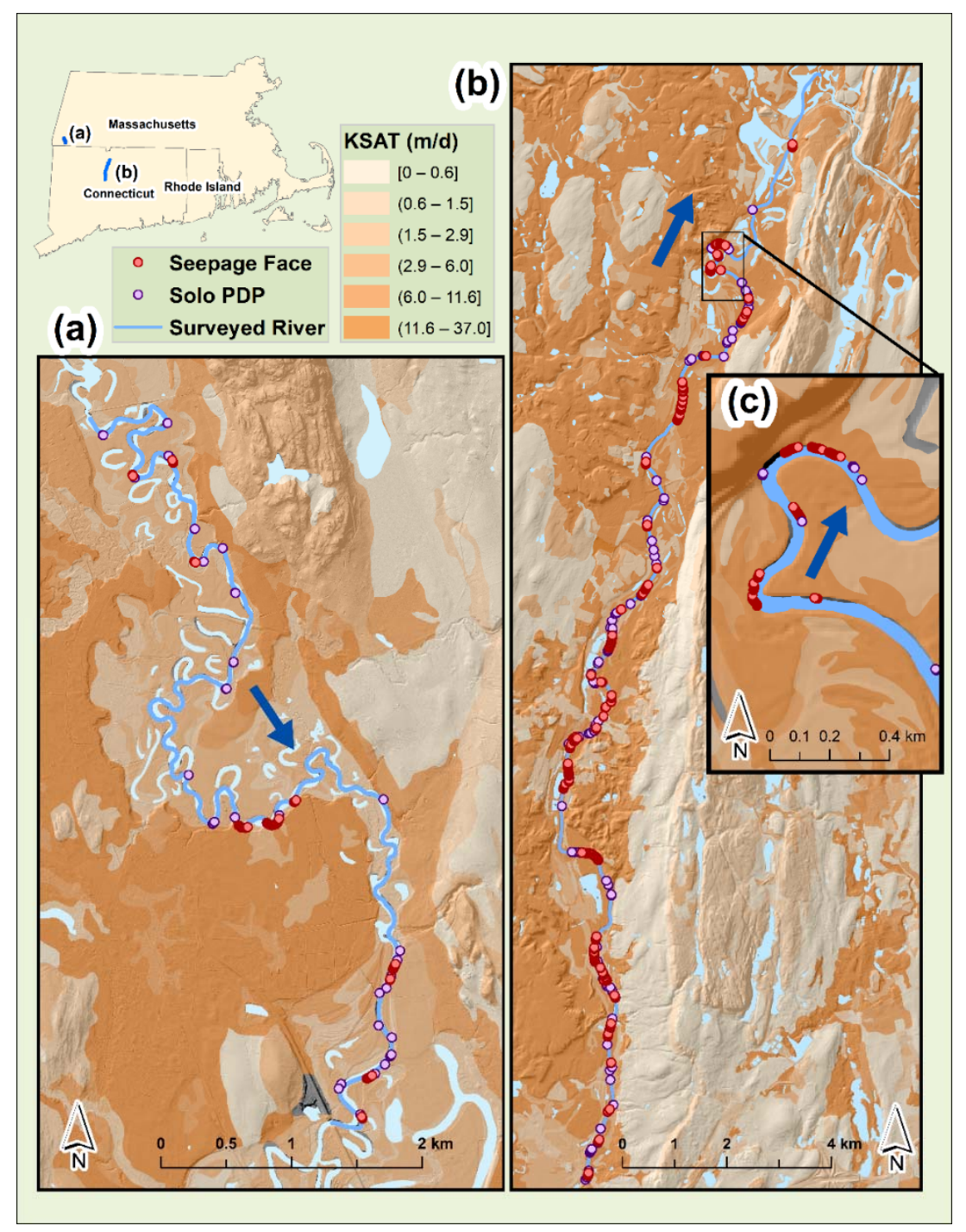

Figure 1. (a) The Housatonic River and (b) Farmington River fifth-order study reaches are shown in the context of surficial soils (SSURGO) saturated hydraulic conductivity (KSAT), along with PDPs (light pink) and more extensive seepage faces (dark pink) located with handheld thermal IR. Panel (c) shows a zoomed section of the Farmington River reach where seepage faces and PDPs occur along zones of relatively high apparent hydraulic conductivity sediments. Dark blue arrows indicate flow direction. 


\subsection{Thermal Infrared Imaging of Discharge Zones}

To map riverbank groundwater discharge zones along the two experimental river reaches, thermal IR data were collected by drone and handheld platforms. Early in the study, we focused on the evaluation of drone-based data, due to the potential benefits in comprehensive and efficient spatial coverage, use of nadir (overhead vertical) viewpoint, and safety, as discussed by [41]. In total, 15 independent drone surveys were performed in 2019, covering approximately 10 contiguous $\mathrm{km}$ of the Farmington River, a forested headwater stream reach, and two wetlands. Flights were conducted predominantly during the winter and early spring seasons of 2019 when leaves were not present on deciduous trees and riverbank vegetation cover was minimized, as compared to the growing season. Under cold conditions groundwater discharge is often relatively warm and buoyant, often creating larger bank, and water surface thermal anomalies to be located via thermal IR compared to the summer season when discharge is relatively cold and dense, and tends to plunge in surface water. However, in our study area, winter and spring river flows are generally highest, which may serve to reduce water surface thermal anomalies due to enhanced hydrodynamic mixing. All drone flights were conducted in the early morning or in evening with a DJI Matrice 100 multirotor small unoccupied aircraft system equipped with an ICI 9640 thermal IR camera $(640 \times 480$ pixels, $7.0-14 \mu \mathrm{m}$ range). Images were generally collected from $120 \mathrm{~m}$ above the ground surface, and forward and horizontal overlap of images was targeted at $80 \%$. All thermal image data were processed using structure from motion techniques into orthomosaics with Agisoft Photoscan software, as described in more detail by [47].

Qualitative assessment of the drone-based thermal IR imaging data indicated that multiscale preferential discharge processes could successfully be mapped across the more open, slow flowing wetland sites, as demonstrated in Figure 2a and in previous research by our group [44]. However, along the mainstem riverbank, preferential discharges were more difficult to discern with confidence, presumably due to relatively small spatial footprints and interference from riparian tree and root cover. We conducted concurred handheld thermal IR surveys from watercraft at similar times to the drone flights (procedure described below), which located numerous riverbank discharges that were not evident in the arial thermal IR imagery, either in singular still or processed orthomosaics images. Many observed PDPs were associated with the base of trees or located along heavily wooded banks, as described in Section 3.2. However, several anthropogenic stormflow discharges were well captured in the drone-based data and derived thermal orthoimages, along with multiscale groundwater-dominated tributary confluences that appeared warmer than the mainstem river flow (Figure $2 b$ ). These findings agree with the airborne thermal IR imaging of [17,48], where stormwater inflows and tributaries were also captured. The study of [17] was also successful in mapping large riverbank springs by helicopter along a Canadian river, but those features created river water surface thermal anomalies, presumably due to the combination of high discharge and favorable river hydrodynamics, where in our study few river surface thermal plumes associated with PDPs were noted. As such, drone-based infrared imaging was discontinued for this study of riverbank PDPs in favor of watercraft-based handheld thermal IR surveys complimented by direct bank temperature measurements. 

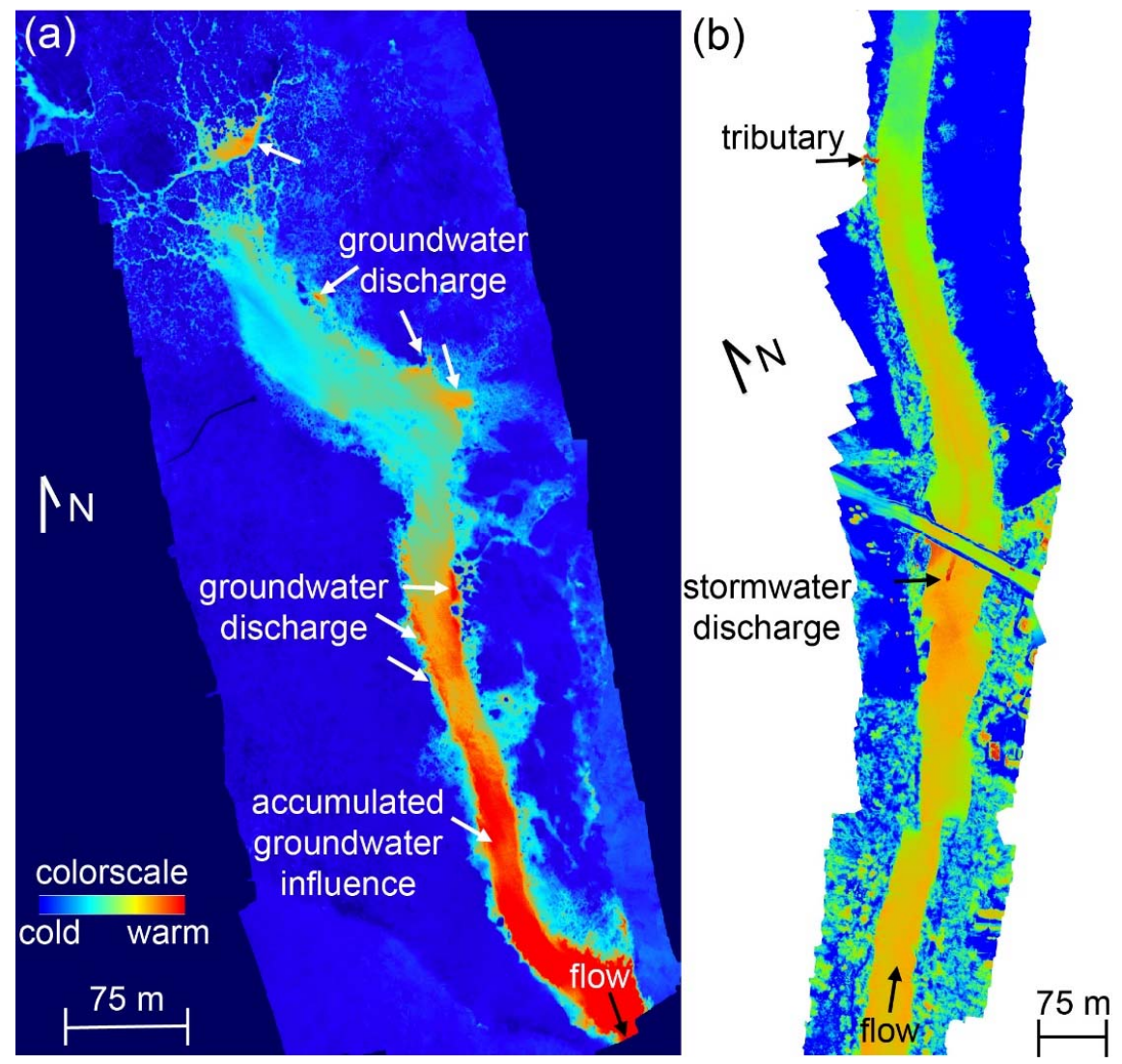

Figure 2. (a) A thermal IR ortho image generated from drone-based data collected over a wetland in the Farmington River headwaters and indicating multi-scale preferential groundwater discharge processes; (b) A drone-based thermal IR ortho image from a section of mainstem Farmington River that captured a midstream stormwater discharge and groundwater-rich tributary inflow.

\subsection{Direct Discharge and Riverbank Sediment Observations}

We conducted spatially comprehensive thermal IR surveys along the Farmington and Housatonic reaches by paddling canoes within approximately five meters of both river banksides and imaging with handheld thermal cameras (FLIR models e8 and t540, Wilsonville, OR, USA). Handheld thermal surveys were completed during late summer baseflow (July-September 2019) when surface water temperatures are high $\left(>15^{\circ} \mathrm{C}\right)$ relative to groundwater temperatures (typically approximately $9-13{ }^{\circ} \mathrm{C}$ ) in southern New England $[25,49]$. By viewing the handheld thermal IR camera screens in real time, rather than during a later processing step, suspected riverbank discharge zones could be investigated further as part of a contiguous and efficient survey process. For example, we also used digital thermometers (precision of $0.1^{\circ} \mathrm{C}$ ) to directly measure bank sediment temperatures at suspected PDPs located with thermal IR $\left(12.8^{\circ} \mathrm{C}\right.$ average for Farmington River reach, and $12.4{ }^{\circ} \mathrm{C}$ average for the Housatonic River reach) and visible signs of discharge flow were also noted. Groundwater discharge locations were mapped using GPS coordinates (Garmin GPSMap 64s $\times$, Olathe, KS, USA), and the longitudinal extent of PDPs and discharge faces along the riverbank were measured with a tape. We subjectively defined groundwater seepages faces to be regions of groundwater greater than $10 \mathrm{~m}$ in longitudinal extent (not analyzed for physical controls as part of this study) and PDPs to be less than $10 \mathrm{~m}$ in longitudinal extent (the focus of this study). We considered individual groundwater discharge points or seepage faces to be separate and distinct from others if they were bounded on both sides by over $10 \mathrm{~m}$ of non-discharge bank sediment.

We used push-point Henry Samplers (MHE Products, East Tawas, MI, USA) to sample discharge water $20 \mathrm{~cm}$ into PDP sediments. Incoming groundwater was pulled through the well until the water ran clear using a $60 \mathrm{~mL}$ Luer-lock syringe. We used a calibrated 
YSI-6000 or YSI-Pro (YSI Inc., Yellow Springs, OH, USA) to record discharge water specific conductance, temperature, and dissolved oxygen. Surficial sediment samples were collected at the coldest surface location of the PDPs. Sediment particle size was analyzed using the hydrometer method. Thermal conductivity and diffusivity were measured using a KD2Pro sensor (Decagon Devices Inc., Pullman, Washington, DC, USA). These thermal property data were collected to enable potential modeling of heat transport processes (not shown here), and since thermal conductivity and diffusivity are often related to sediment characteristics that influence flow and biogeochemical reaction [50]. Wet sediment samples were weighed then passed through a $2 \mathrm{~mm}$ sieve to remove large gravel and organic debris. The samples were then placed into a $105^{\circ} \mathrm{C}$ oven for $72 \mathrm{~h}$ to evaporate all moisture. Oven dry sediment samples were mixed with a $5 \%$ sodium hexametaphosphate dispersing solution then placed on a shaker table at 180 oscillations per minute for $16 \mathrm{~h}$. Sediment solutions were then transferred into a one-liter graduated cylinder, and deionized water was added to bring the solution to one liter. The solution was then fully mixed by repeatedly inverting the graduated cylinder for $30 \mathrm{~s}$. We immediately recorded a hydrometer measurement as \% sand and again after $8.5 \mathrm{~h}$ (as \% clay). We used the loss on ignition method to quantify the percent organic matter of each sediment sample. Additionally, $5.0 \mathrm{~g}$ of oven dried sample was burned at $550{ }^{\circ} \mathrm{C}$ for $4 \mathrm{~h}$, and percent organic matter was calculated as the difference of dried and burned sample mass divided by dried sample mass.

Early in the riverbank thermal IR scanning process we found that PDPs were sometimes directly associated with tree roots and tree root masses. Therefore, the survey process was adjusted to note such associations for the remaining PDP locations. This resulted in a qualitative assessment of the fraction of PDPs that occurred directly adjacent to riparian tree root structures, and is considered a conservative estimate.

\subsection{Large-Scale Soils Database Characteristic Extraction}

We compared soil parameters extracted at observed PDP locations to average soil parameters extracted from riverbank points spaced $50 \mathrm{~m}$ apart along both banks over the entire length of each study reach. For analysis of soils characteristics along the study river sections, we joined tabular data of area- and depth-weighted averages of SSURGO variables [51] with state Gridded Soil Survey Geographic (gSSURGO) database shapefiles (Soil Survey Staff 2020, accessed 4 October 2021, https:/ /gdg.sc.egov.usda.gov) using NRCS map unit keys, or 'MUKEY' identifications. Examples of the spatial distribution of surficial soil saturated hydraulic conductivity (KSAT) along the study river reaches are shown in Figure 1. We then linked our mapped PDP location dataset [52] with soil layers using the Near (Analysis) tool in ArcMAP 10.8.1's Proximity toolbox (Esri, Redlands, CA, USA). The accuracy of the near analysis was manually inspected for instances in which portions of a seepage face or PDP intersected multiple soil types. When instances such as this occurred, we chose the spatially predominant intersecting soil type for our analysis. Soil samples from PDPs were also spatially linked to SSURGO variables for comparison.

\section{Results}

\subsection{Mapping of Riverbank PDPs}

Overall, 104 distinct PDPs (average of 4 PDPs per river $\mathrm{km}$ ) were observed along the $26 \mathrm{~km}$ study reach of the Farmington River, compared to 31 PDPs (average of 2.5 PDPs per river $\mathrm{km}$ ) found along the $12 \mathrm{~km}$ study reach of the Housatonic River (Figure 1, [52]). Similarly, many more extensive seepage faces were observed along the Farmington River study reach. Along both reaches, the spatial distribution of PDPs tended to be irregular, and while weighted toward the outside of meander bend cutbanks, was not clearly related to river morphology. Overall, PDP locations were more evenly distributed along the Farmington River. We observed the occurrence of individual PDPs without additional discharge locations for hundreds of meters laterally along the bank, and we also observed PDPs adjacent to large seepage faces (i.e., just over $10 \mathrm{~m}$ away). 


\subsection{Direct Discharge and Riverbank Sediment and Tree Roots Observations}

We observed surface macropores at more than half of the PDP locations, and some of these were directly associated with masses of tree roots protruding from the riverbanks (e.g., Figure 3). Along the Farmington River reach, 34 of the 104 mapped PDPs (33\%) occurred along the interface or just below riparian tree root masses. Far fewer PDPs were mapped along the Housatonic River reach (31), and of those, seven PDPs co-occurred with tree roots, or $23 \%$ of the surveyed total.

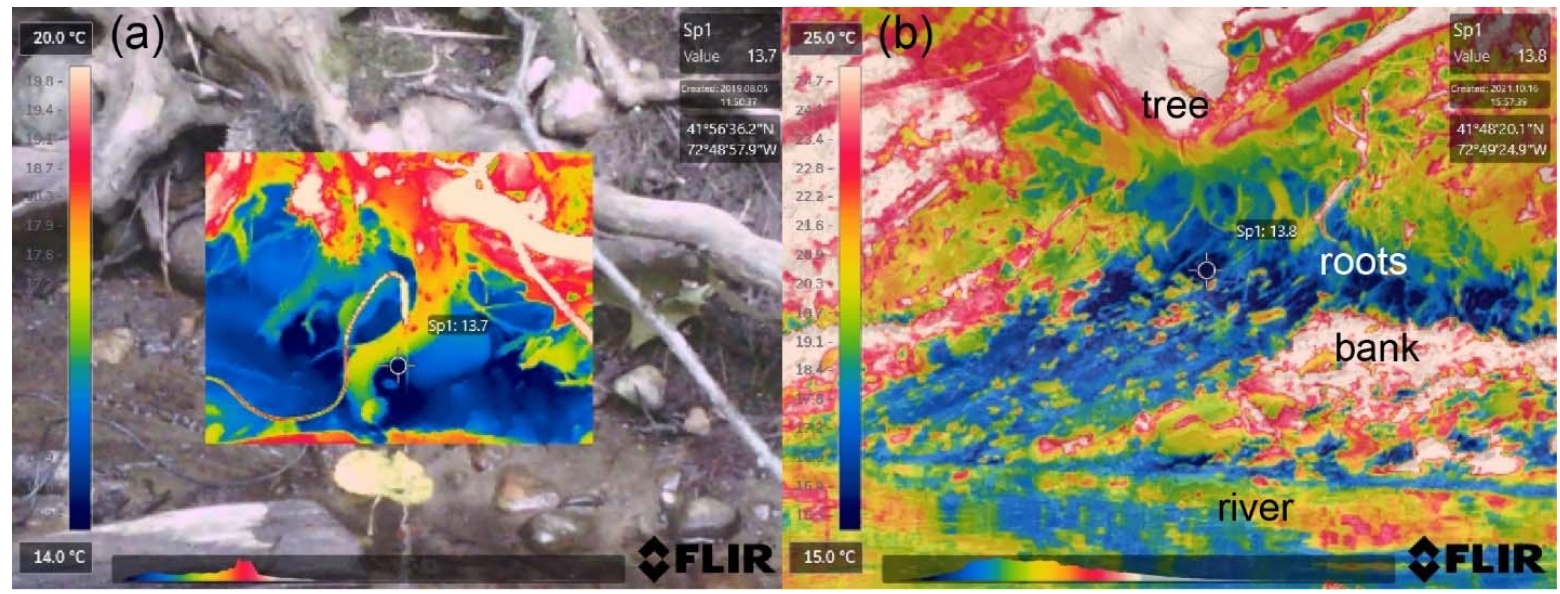

Figure 3. Preferential groundwater discharge directly associated with tree roots protruding from the bank along a (a) third-order, and (b) fifth-order stream section in the Farmington River watershed. The coldest discharge temperature at bank surface indicated by IR imaging within the field of view was similar at both sites at approximately $13.7^{\circ} \mathrm{C}$.

Dissolved oxygen measured in discharge water at a subset of the Farmington River PDP sites ranged from 1.44 to $8.12 \mathrm{mg} / \mathrm{L}$, indicating a broad range in redox conditions of the emergent groundwater (Figure 4). No apparent relations were observed between measured surficial soils characteristics and dissolved oxygen, potentially since Farmington Riverbank PDP locations had low variation in sediment content: they were generally $>95 \%$ sand content and low in clay and organic matter content.

(a)

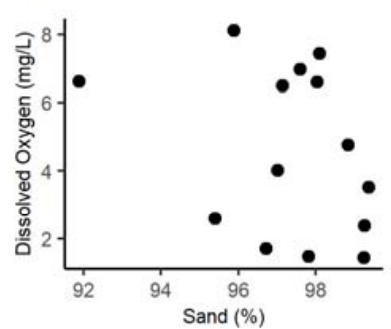

(d)

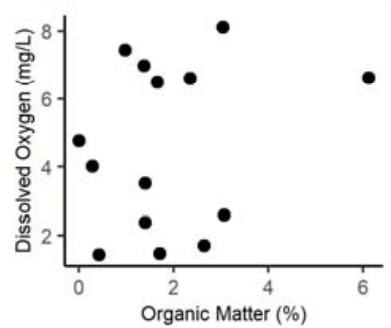

(b)

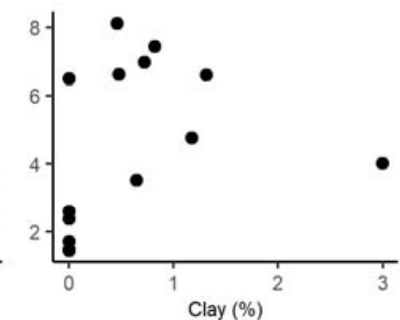

(e)

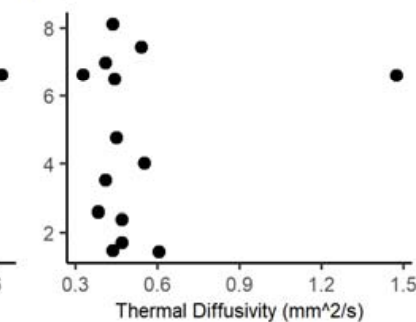

(c)

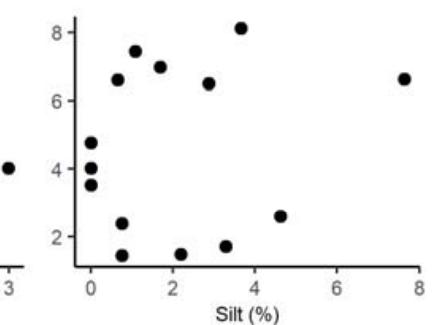

(f)

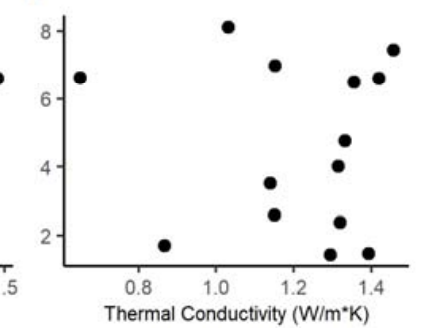

Figure 4. Dissolved oxygen measured in groundwater discharge compared to (a) \% sand, (b) \% clay, (c) \% silt, (d) \% organic matter, (e) thermal diffusivity, and (f) thermal conductivity measured in the local surficial soil sample for a subset of PDPs $(n=14)$ in the Farmington River study reach. 


\subsection{Large-Scale Soils Database Characteristic Comparison}

We found substantial differences in several SSURGO bank soil parameters between the Housatonic and Farmington River reaches, but found no major differences for PDP locations vs. the average bank soil characteristics within either study reach (Table 1 , Figures 5 and 6). For example, KSAT had a mean of $9.3 \mathrm{~m} /$ day (3.3 standard deviation, SD) for the Farmington reach, but was only $1.7 \mathrm{~m} /$ day (1.2 SD) for the Housatonic (Table 1). Bank sediment sand content was approximately $2 \times$ higher along the Farmington reach and clay content $2 \times$ lower compared to the Housatonic reach, while total porosity was similar. The mean KSAT was slightly higher for Farmington and Housatonic PDP sites relative to their respective average datasets, but those differences were well within one SD of either dataset.

Table 1. Mean (standard deviation) of SSURGO parameters extracted for the riverbank of the study reaches along the entire riverbank (average) and for PDP locations (PDP). OM, organic matter.

\begin{tabular}{cccccc}
\hline Dataset & $\begin{array}{c}\text { KSAT } \\
(\mathbf{m} / \text { day) }\end{array}$ & $\begin{array}{c}\text { Porosity } \\
\mathbf{( \% )}\end{array}$ & $\begin{array}{c}\text { Sand } \\
\mathbf{( \% )}\end{array}$ & $\begin{array}{c}\text { Clay } \\
\mathbf{( \% )}\end{array}$ & $\begin{array}{c}\text { OM } \\
\mathbf{( \% )}\end{array}$ \\
\hline $\begin{array}{c}\text { Farmington } \\
\text { Average } \\
(n=1078)\end{array}$ & 9.3 & 48.9 & 76.7 & 3.2 & 0.8 \\
\hline $\begin{array}{c}\text { Farmington } \\
\text { PDP } \\
(n=104)\end{array}$ & $(3.3)$ & $(1.4)$ & $(13.5)$ & $(2.1)$ & $(0.3)$ \\
\hline $\begin{array}{c}\text { Housatonic } \\
\text { Average } \\
(n=527)\end{array}$ & $(2.2)$ & 48.9 & 81.2 & 2.5 & 0.8 \\
\hline $\begin{array}{c}\text { Housatonic } \\
\text { PDP }\end{array}$ & $(1.7$ & 49.6 & $(8.5)$ & $(1.5)$ & $(0.2)$ \\
$(n=31)$ & $(1.7)$ & $(2.5)$ & $(11.3)$ & $(1.1)$ & 2.3 \\
\hline
\end{tabular}

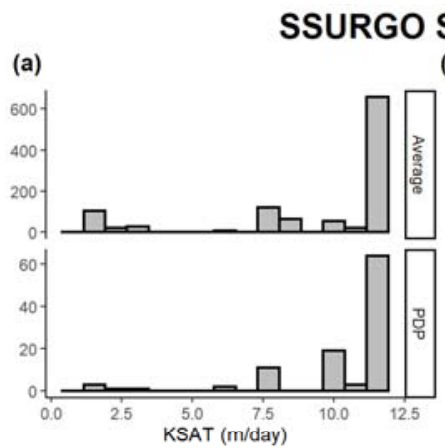

(b)

(c)

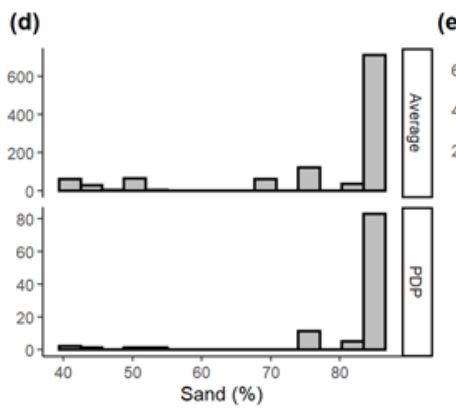

(e)

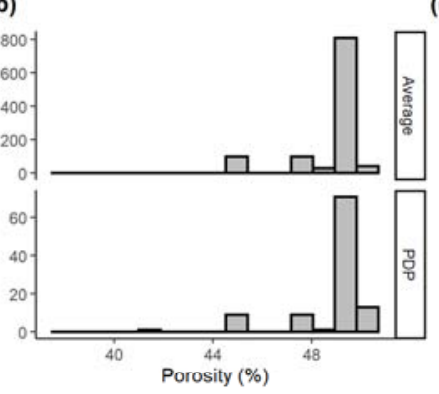

River

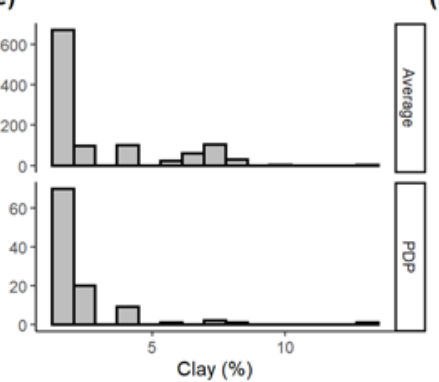

(f)
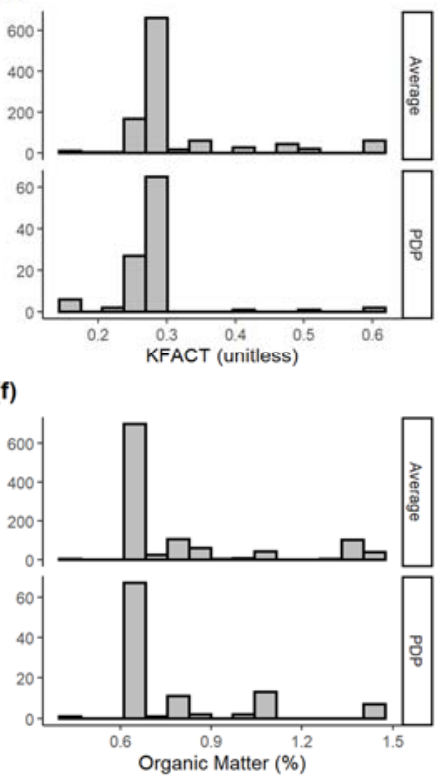

Figure 5. Soil parameters extracted from the SSURGO dataset at PDP locations and the average bank soil parameters from both banks of the Farmington River reach for (a) KSAT, (b) porosity, (c) hydraulic conductivity factor (KFACT), (d) sand \%, (e) clay \%, and (f) organic matter \%. 


\section{SSURGO Soil Characteristics, Housatonic River}

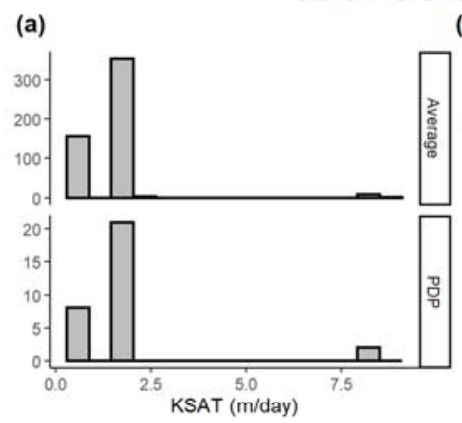

(b)

(c)
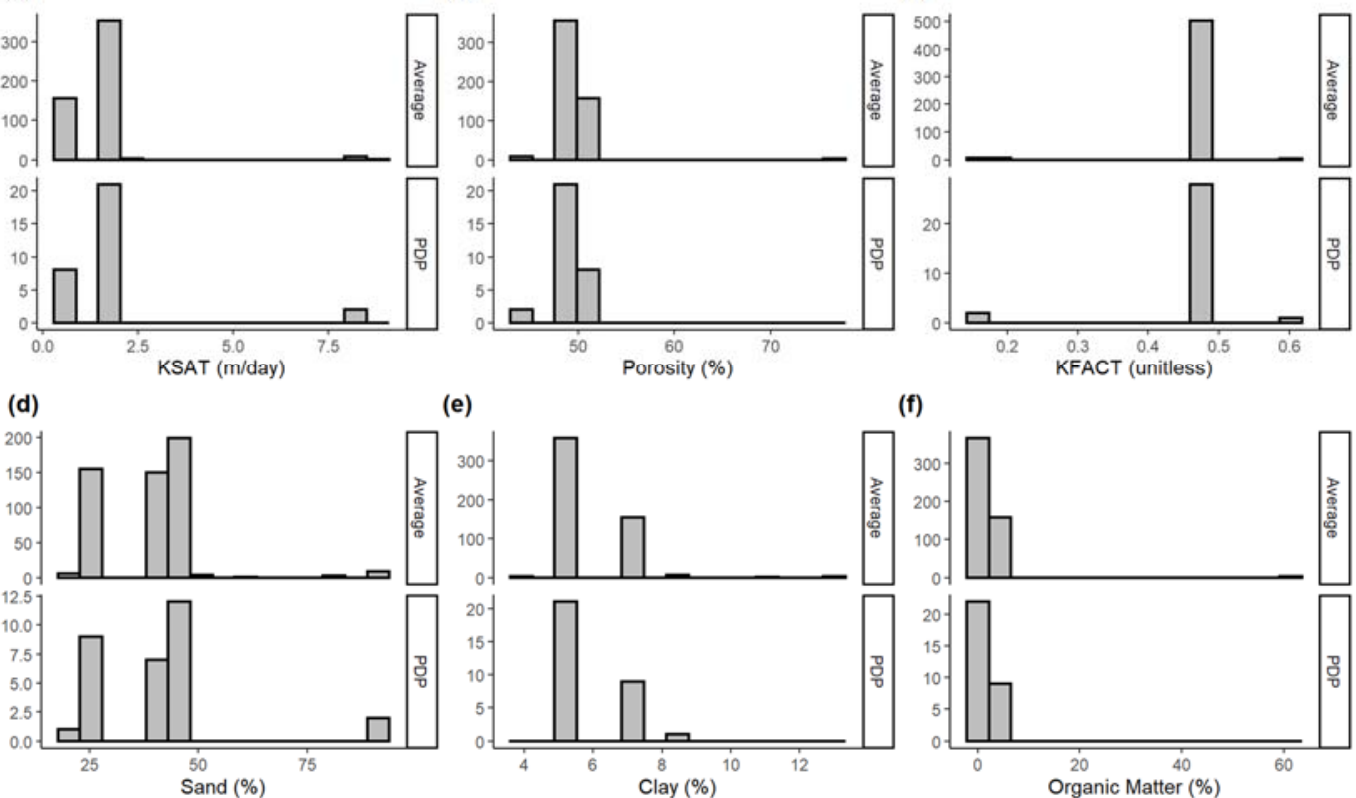

(e)
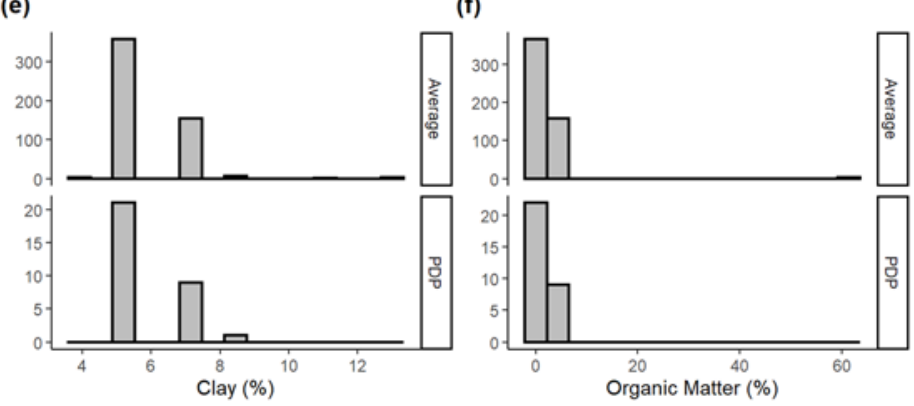

Figure 6. Soil parameters extracted from the SSURGO dataset at PDP locations and the average bank soil parameters from both banks of the Housatonic River reach for (a) KSAT, (b) porosity, (c) hydraulic conductivity factor (KFACT), (d) sand \%, (e) clay \%, and (f) organic matter \%.

\section{Discussion and Conclusions}

\subsection{Using Drone and Handheld Thermal IR to Map Riverbank PDPS}

For this study, we used thermal IR to comprehensively map the occurrence of PDPs along the banks of two mainstem rivers cutting through glaciated terrain. Drone (from approximately $120 \mathrm{~m}$ above ground level) and handheld (from watercraft) thermal IR methods were concurrently tested for this application over a subsection of the Farmington River reach, and handheld imaging paired with direct measurements was found to be more reliable in remotely locating multiscale PDPs. Drone imaging performed better in more open-canopy wetland settings and for mapping higher flow discharges to the mainstem river (i.e., storm inflows, tributaries). Large deciduous riparian trees tended to obscure drone-based thermal IR imaging of riverbank PDPs even in winter, particularly as many discharge zones were located directly underneath protruding tree root masses, and the canopy height combined with variable bank topography precluded lower altitude flights that may have increased spatial resolution. Given the importance of wooded riparian zone buffers at intercepting nutrients and contaminants [53], drone-based imaging of riverbank features is likely to be challenged by canopy cover in a range of systems worldwide. Future drone-based surveys could attempt imaging at lower angles to the bank to 'see' under the tree canopy from the channel center, rather than flying nadir as performed here, though that would necessitate lower attitude flights. The handheld IR surveys via watercraft were more time consuming per area, but also allowed important direct data (bank temperature, observations of flow, water chemistry) to be collected at apparent PDPs indicated by thermal IR, which increased the fidelity of our seep identifications.

\subsection{Large-Scale and Localized Physical Data from Riverbank PDPs}

Farmington riverbank soils are generally described as 'well' or 'excessively' drained with high sand content in the SSURGO dataset, while the Housatonic soils are a mix of 'well', 'moderate', and 'poorly' drained soils. These large-scale differences in soil type impact the ability of riverbank materials to accommodate temporary bank storage during high flow events and the development of perennial groundwater discharge zones in the form of PDPs. KSAT averaged $~ 5 \times$ higher along the Farmington (on average and at PDP 
locations) compared to the Housatonic (Table 1). There were also many more mapped PDPs and extensive seepage faces along the Farmington River reach (Figure 1), and overall, the discharge locations showed more even spatial distribution, compared to the Housatonic River reach, where there were several $1 \mathrm{~km}+$ sections with only a single mapped PDP (Figure 1).

These disparate patterns in discharge occurrence between two nearby mainstem rivers draining glaciated terrain are likely influenced by the general shift in valley floor and riverbank soil permeability that is captured in the SSURGO dataset, but other physical factors certainly contribute as well. For example, the Housatonic River drains an unconstrained valley compared to the Farmington River that drains a partially confined valley. In addition, while the greater sinuosity of the Housatonic might be expected to generate PDPs at migrating cutbanks, reduced lateral valley-scale hydraulic gradients could also cause reduced lateral groundwater discharge through bank sediments [16]. Using airborne thermal IR collected over several hundred $\mathrm{km}$ of riverscape to map multiscale bank discharge features, Dugdale et al. [42] posited that semi-confined alluvial river valleys create a 'sweet spot' of hydraulic and geomorphic factors to increase the density of riverbank PDPs, and our findings seem to support that concept. However, our data do not capture potential submerged riverbed groundwater discharges, which might be expected to dominate in a lower lateral gradient, unconfined valley setting compared to bankside PDPs.

Although at the alluvial valley scale the gSSURGO soil layers are mapped at relatively high spatial resolution (Figure 1), the soil units may be too generalized to capture the physical riverbank controls on PDP occurrence at the $<10 \mathrm{~m}$ scale. We did not observe compelling differences between average bank and PDP soil properties for either study reach, though the Farmington River PDP locations had fewer low-end outliers of KSAT and sand content relative to average bank properties (Figure 5). Our direct sediment samples collected at a subset of Farmington PDP locations did indicate the SSURGO data universally underestimated sand content (Appendix A), though our bank sediment interface sediment sampling technique was likely influenced in places by contemporary alluvial sand deposits that might differ from the bulk bank material. We observed a wide range of redox conditions in Farmington River discharge water, with visible iron oxide staining at dozens of PDP locations, even though the SSURGO and measured organic matter content was universally low (Figures 4 and 5). Further, the lack of observed relation between dissolved oxygen in discharge water and several measured soil parameters that are expected to influence aerobic respiration based on increased reactive surface area indicates flowpath-scale or localized upgradient reactive processes may be more important to determining the redox condition of discharge water at these PDPs than bank soils. However, our soil samples were all collected via cores directly at the discharge interface that may be reworked by scour and alluvial deposition, and may not reflect upgradient sediment conditions within the larger riverbank and riparian river buffer.

One early hypothesis of this study was that secondary bank structures such as tree roots and macropores might be generally more important in creating PDPs along lower permeability bank sediments, creating conduits for short-circuit flow. As noted by [2], we found macropore discharge directly associated with masses of tree roots protruding from bank sediments. Tree roots were noted at approximately $\frac{1}{4}$ of PDP zones, but the fraction was somewhat higher along the Farmington relative to Housatonic reaches (33\% vs. 23\%), where bank soils were universally higher in permeability, and multiple large seepage faces were observed to occur along sand and gravel dominated bank sections (Figure 1). Though a direct comparison is hindered by the overall low PDP count along the Housatonic River reach, this result indicates secondary, highly localized bank structures, such as riparian tree roots, are important to creating PDPs along a range of riverbank sediment permeabilities including on the higher end. This finding is consistent with thermal IR observations we have made across the Farmington River watershed, where groundwater discharge may be focused at the base of dead trees or other macropores, even in sand and gravel bank deposits. Preferential groundwater discharge processes have been invoked to explain why 
observed contaminant transport rates often exceed rates predicted by models that simplify geologic complexity $[15,19]$, and our study indicates PDPs may be widespread along gaining mainstem rivers, and driven by a combination of large-scale bank soil permeability and local-scale bank sediment structures.

\subsection{Summary Thoughts}

The motivation of this study was to assess the potential predictability of riverbank groundwater discharge zone occurrence based on existing soils maps or directly measured soil properties based on observed PDPs mapped in detail across $10 \mathrm{~s}$ of river $\mathrm{km}$. We found that thermal IR imaging from small watercraft can efficiently map PDP locations across relatively long reaches of mainstem rivers with mature riparian tree canopy. Such maps guide direct sediment and chemical sampling and cross-referencing with large-scale geologic maps or models to investigate the physical controls on PDP occurrence. We did not find clear differences in SSURGO variables polygons for PDP locations compared to the average river reach bank soil characteristics along either reach. However, more PDPs per unit distance were found along the partially confined Farmington River, where several parameters also indicated generally higher permeability soils compared to the unconfined valley Housatonic River mainstem reach. Previous large-scale studies of river temperature have found enhanced groundwater-river connectivity in areas of permeable surficial soils and fractured bedrock [54], which follows theory. It might be assumed that such well groundwater-connected river reaches will support thermal refuge and refugia [55], although O'Sullivan et al. [54] also found that a stream draining high permeability glaciofluvial outwash material was relatively warm in summer; presumably due to the influence of shallow groundwater flowpaths that absorb surface heat seasonally [56]. That research demonstrates that the physical drivers of groundwater discharge water quality and temperature are complex, necessitating specific study of discrete mainstem river PDPs, in addition to large-scale baseflow analysis based on river hydrographs.

As baseflow is the aggregate of all groundwater discharge and long-term soil water storage and release processes, riverbank PDPs contribute to maintaining critical lowflows, create unique niche aquatic habitats [8], and in providing connectivity between aquifer contaminants and river corridors [15]. Though recent work in a river with similar hydrogeology to our study reaches found that a combination of average watershed-scale parameters related to topography, geology, and soil type explained more than half of the baseflow variability [57], we did not find similar clear explanatory power regarding bank soil type at the scale of individual PDPs. The lack of relationship between PDPs and soil properties could result from the gSSURGO polygons being too coarse in critical parameter description (such as KSAT) to be expected to capture the geologic drivers of sub-10 m PDP features along mainstem rivers. New large-scale geologic mapping and modeling techniques are increasing accuracy in surficial soils maps, including parameters that are directly related to groundwater discharge, such as depth to bedrock and zones of rapid slope erosion, which may lead to greater predictive understanding of riverbank groundwater discharge zonation (e.g., [22-24,58]). Additionally, the co-occurrence of riparian tree root masses was noted at many PDP sites along the study reaches, indicating the importance of localized macropores in controlling the spatial distribution of PDPs in both higher and lower permeability bank soils. Future research could focus more specifically on riverbank vegetation root type observed directly at discharge locations as certain species might be prone to creating flow-bearing macropores through bank sediments. Such fine scale physical processes are not likely to be well represented in even emerging remote geologic mapping techniques, suggesting critical needs for pairing advances in field-based assessments, such as the incorporation of thermal IR, into the typical hydrogeological toolkit.

Author Contributions: Conceptualization, M.A.B., A.M.H.; methodology, M.A.B., K.E.J., E.M.M.; software, E.M.M.; data curation, K.E.J., F.L., E.M.M.; writing-original draft preparation, M.A.B., F.L., A.B., E.M.M. and K.E.J.; writing-review and editing, M.A.B., K.E.J. and A.M.H.; visualization, 
M.A.B. and K.E.J.; supervision, M.A.B. and A.M.H.; funding acquisition, M.A.B. and A.M.H. All authors have read and agreed to the published version of the manuscript.

Funding: This research was funded by US National Science Foundation Division of Earth Sciences award (\#1824820), and the U.S. Geological Survey (USGS) Toxic Substances Hydrology Program.

Data Availability Statement: Data collected for this study are available at doi.org/10.5066/P915E8JY [52].

Acknowledgments: We thank Adam Haynes, Mark Harvey, Kenneth Bell, and Huayile Zhang for field data collection and data processing assistance. Any use of trade, firm, or product names is for descriptive purposes only and does not imply endorsement by the U.S. Government.

Conflicts of Interest: The authors declare no conflict of interest. The funders had no role in the design of the study; in the collection, analyses, or interpretation of data; in the writing of the manuscript, or in the decision to publish the results.

\section{Appendix A}
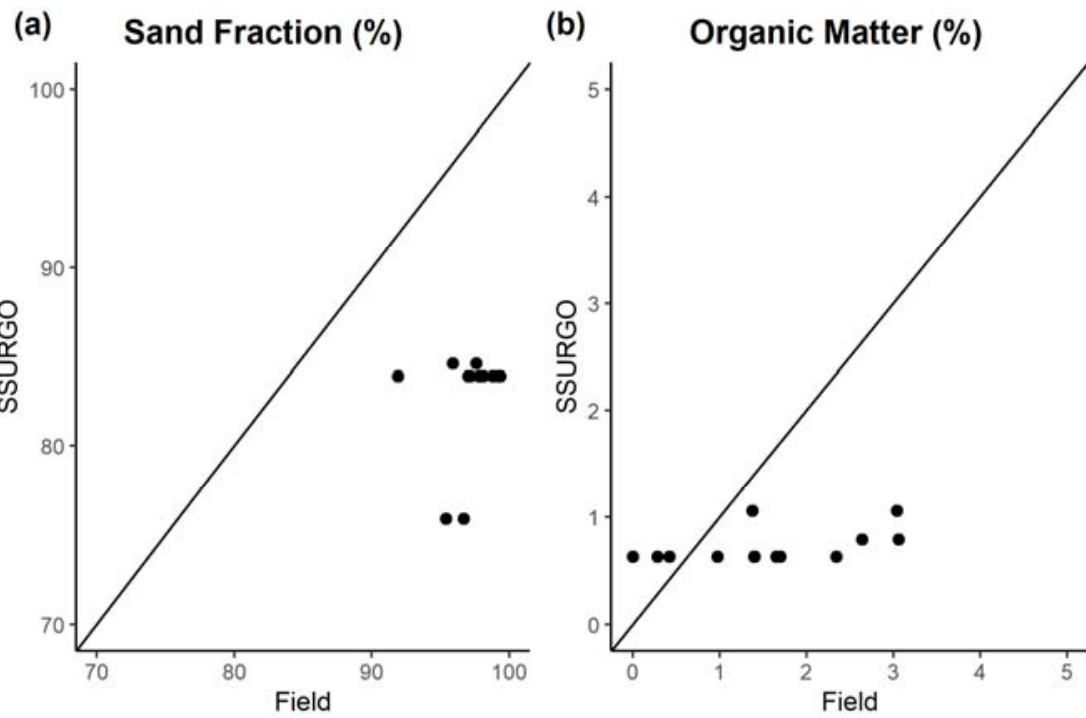

Figure A1. (a) Measured sand fraction (\%) and (b) organic matter content (\%) of bank soils at a subset of Farmington River PDP locations compared to the analogous derived SSURGO parameters.

\section{References}

1. Beven, K.; Germann, P. Macropores and water flow in soils revisited. Water Resour. Res. 2013, 49, 3071-3092. [CrossRef]

2. Hester, E.T.; McEwen, A.M.; Kim, B.J.; Rost, E.A. Abundance, distribution, and geometry of naturally occurring streambank soil pipes. Freshw. Sci. 2020, 39, 735-751. [CrossRef]

3. Mohammed, A.A.; Kurylyk, B.L.; Cey, E.E.; Hayashi, M. Snowmelt Infiltration and Macropore Flow in Frozen Soils: Overview, Knowledge Gaps, and a Conceptual Framework. Vadose Zone J. 2018, 17, 180084. [CrossRef]

4. Sidle, R.C.; Tsuboyama, Y.; Noguchi, S.; Hosoda, I.; Fujieda, M.; Shimizu, T. Stormflow generation in steep forested headwaters: A linked hydrogeomorphic paradigm. Hydrol. Process. 2000, 14, 369-385. [CrossRef]

5. Menichino, G.T.; Hester, E.T. The effect of macropores on bi-directional hydrologic exchange between a stream channel and riparian groundwater. J. Hydrol. 2015, 529, 830-842. [CrossRef]

6. Liu, G.; Knobbe, S.; Butler, J.J. Resolving centimeter-scale flows in aquifers and their hydrostratigraphic controls. Geophys. Res. Lett. 2013, 40, 1098-1103. [CrossRef]

7. Briggs, M.A.; Hare, D.K. Explicit consideration of preferential groundwater discharges as surface water ecosystem control points. Hydrol. Process. 2018, 32, 2435-2440. [CrossRef]

8. Ebersole, J.L.; Liss, W.J.; Frissell, C.A. Cold water patches in warm streams: Physicochemical characteristics and the influence of shading. J. Am. Water Resour. Assoc. 2003, 59860, 355-368. [CrossRef]

9. Michael, H.A.; Post, V.E.A.; Wilson, A.M.; Werner, A.D. Science, society, and the coastal groundwater squeeze. Eos. Trans. Am. Geophys. Union 2017, 53, 2610-2617. [CrossRef]

10. Huryn, A.D.; Gooseff, M.N.; Hendrickson, P.J.; Briggs, M.A.; Tape, K.D.; Terry, N.C. Aufeis fields as novel groundwater-dependent ecosystems in the arctic cryosphere. Limnol. Oceanogr. 2021, 66, 607-624. [CrossRef] 
11. Hayashi, M.; Rosenberry, D.O. Effects of ground water exchange on the hydrology and ecology of surface water. Ground Water 2002, 40, 309-316. [CrossRef]

12. Singha, K.; Navarre-Sitchler, A. The importance of groundwater in critical zone science. Groundwater 2021, 1-8. [CrossRef]

13. Thomas, J.C.; McMahon, P.B.; Arnold, L.R. Groundwater Quality and Hydrology with Emphasis on Selenium Mobilization and Transport in the Lower Gunnison River Basin, Colorado, 2012-2016. Sci. Investig. Rep. 2019. [CrossRef]

14. Briggs, M.A.; Tokranov, A.K.; Hull, R.B.; LeBlanc, D.R.; Haynes, A.B.; Lane, J.W. Hillslope groundwater discharges provide localized stream ecosystem buffers from regional per- and polyfluoroalkyl substances contamination. Hydrol. Process. 2020, 34, 2281-2291. [CrossRef]

15. Barclay, J.R.; Starn, J.J.; Briggs, M.A.; Helton, A.M. Improved Prediction of Management-Relevant Groundwater Discharge Characteristics Throughout River Networks. Water Resour. Res. 2020, 56, e2020WR028027. [CrossRef]

16. Winter, T.C.; Harvey, J.W.; Franke, O.L.; Alley, W.M. Ground Water and Surface Water: A Single Resource; U.S. Geological Survey: Reston, VA, USA, 1998; Volume 1139, p. 79.

17. O'Sullivan, A.M.; Devito, K.J.; Ogilvie, J.; Linnansaari, T.; Pronk, T.; Allard, S.; Curry, R.A. Effects of Topographic Resolution and Geologic Setting on Spatial Statistical River Temperature Models. Water Resour. Res. 2020, 56, e2020WR028122. [CrossRef]

18. Vidon, P.; Allan, C.; Burns, D.; Duval, T.P.; Gurwick, N.; Inamdar, S.; Lowrance, R.; Okay, J.; Scott, D.; Sebestyen, S.; et al. Hot spots and hot moments in riparian zones: Potential for improved water quality management. J. Am. Water Resour. Assoc. 2010, 46, 278-298. [CrossRef]

19. Deitchman, R.S.; Loheide, S.P. Ground-based thermal imaging of groundwater flow processes at the seepage face. Geophys. Res. Lett. 2009, 36, 1-6. [CrossRef]

20. Sebok, E.; Duque, C.; Engesgaard, P.; Boegh, E. Spatial variability in streambed hydraulic conductivity of contrasting stream morphologies: Channel bend and straight channel. Hydrol. Process. 2015, 29, 458-472. [CrossRef]

21. Ikard, S.J.; Briggs, M.A.; Lane, J.W. Investigation of Scale-Dependent Groundwater/Surface- water Exchange in Rivers by Gradient Self-Potential Logging: Numerical Modeling and Field Experiments. J. Environ. Eng. Geophys. 2021, 26, 83-98. [CrossRef]

22. Furze, S.; Sullivan, A.M.O.; Allard, S.; Pronk, T.; Curry, R.A. A High-Resolution, Random Forest Approach to Mapping Depth-toBedrock across Shallow Overburden and Post-Glacial Terrain. Remote Sens. 2021, 13, 4210. [CrossRef]

23. Fraser, O.L.; Bailey, S.W.; Ducey, M.J.; McGuire, K.J. Predictive modeling of bedrock outcrops and associated shallow soil in upland glaciated landscapes. Geoderma 2020, 376, 114495. [CrossRef]

24. Prince, A.; Franssen, J.; Lapierre, J.F.; Maranger, R. High-resolution broad-scale mapping of soil parent material using object-based image analysis (OBIA) of LiDAR elevation data. Catena 2020, 188, 104422. [CrossRef]

25. Hare, D.K.; Boutt, D.F.; Clement, W.P.; Hatch, C.E.; Davenport, G. Hydrogeological controls on spatial patterns of groundwater discharge in peatlands. Hydrol. Earth Syst. Sci. 2017, 21, 6031-6048. [CrossRef]

26. Skovdal Christiansen, J.; Thorsen, M.; Clausen, T.; Hansen, S.; Christian Refsgaard, J. Modelling of macropore flow and transport processes at catchment scale. J. Hydrol. 2004, 299, 136-158. [CrossRef]

27. Briggs, M.A.; Hare, D.K.; Boutt, D.F.; Davenport, G.; Lane, J.W. Thermal infrared video details multiscale groundwater discharge to surface water through macropores and peat pipes. Hydrol. Process. 2016, 30, 2510-2511. [CrossRef]

28. Kalbus, E.; Reinstorf, F.; Schirmer, M. Measuring methods for groundwater-surface water interactions: A review. Hydrol. Earth Syst. Sci. 2006, 10, 873-887. [CrossRef]

29. Rosenberry, D.O.; López, J.M.N.; Webb, R.M.T.; Müller, S. Variable seepage meter efficiency in high-permeability settings. Water 2020, 12, 3267. [CrossRef]

30. Banks, E.W.; Shanafield, M.A.; Noorduijn, S.; Mccallum, J.; Lewandowski, J. Active heat pulse sensing of 3-D-flow fields in streambeds. Hydrol. Earth Syst. Sci. 2018, 22, 1917-1929. [CrossRef]

31. Rau, G.C.; Andersen, M.S.; McCallum, A.M.; Roshan, H.; Acworth, R.I. Heat as a tracer to quantify water flow in near-surface sediments. Earth Sci. Rev. 2014, 129, 40-58. [CrossRef]

32. Conant, B. Delineating and quantifying ground water discharge zones using streambed temperatures. Ground Water 2004, 42, 243-257. [CrossRef] [PubMed]

33. Lautz, L.K.; Ribaudo, R.E. Scaling up point-in-space heat tracing of seepage flux using bed temperatures as a quantitative proxy. Hydrogeol. J. 2012, 20, 1223-1238. [CrossRef]

34. McCobb, T.D.; Briggs, M.A.; LeBlanc, D.R.; Day-Lewis, F.D.; Johnson, C.D. Evaluating long-term patterns of decreasing groundwater discharge through a lake-bottom permeable reactive barrier. J. Environ. Manag. 2018, 220, 233-345. [CrossRef]

35. Lowry, C.S.; Walker, J.F.; Hunt, R.J.; Anderson, M.P. Identifying spatial variability of groundwater discharge in a wetland stream using a distributed temperature sensor. Water Resour. Res. 2007, 43. [CrossRef]

36. Matheswaran, K.; Blemmer, M.; Rosbjerg, D.; Boegh, E. Seasonal variations in groundwater upwelling zones in a Danish lowland stream analyzed using Distributed Temperature Sensing (DTS). Hydrol. Process. 2014, 28, 1422-1435. [CrossRef]

37. Sebok, E.; Duque, C.; Kazmierczak, J.; Engesgaard, P.; Nilsson, B.; Karan, S.; Frandsen, M. High-resolution distributed temperature sensing to detect seasonal groundwater discharge into Lake Væng. Water Resour. Res. 2013, 49, 5355-5368. [CrossRef]

38. Rosenberry, D.O.; Briggs, M.A.; Delin, G.; Hare, D.K. Combined use of thermal methods and seepage meters to efficiently locate, quantify, and monitor focused groundwater discharge to a sand-bed stream. Water Resour. Res. 2016, 52, 4486-4503. [CrossRef] 
39. Handcock, R.N.; Torgersen, C.E.; Cherkauer, K.A.; Gillespie, A.R.; Tockner, K.; Faux, R.N.; Tan, J. Thermal Infrared Remote Sensing of Water Temperature in Riverine Landscapes. In Fluvial Remote Sensing for Science and Management; John Wiley \& Sons Inc.: Hoboken, NJ, USA, 2012; pp. 85-113.

40. Baker, E.A.; Lautz, L.K.; McKenzie, J.M.; Aubry-Wake, C. Improving the accuracy of time-lapse thermal infrared imaging for hydrologic applications. J. Hydrol. 2019, 571, 60-70. [CrossRef]

41. Briggs, M.A.; Dawson, C.B.; Holmquist-Johnson, C.L.; Williams, K.H.; Lane, J.W. Efficient hydrogeological characterization of remote stream corridors using drones. Hydrol. Process. 2019, 33, 316-319. [CrossRef]

42. Dugdale, S.J.; Bergeron, N.E.; St-Hilaire, A. Spatial distribution of thermal refuges analysed in relation to riverscape hydromorphology using airborne thermal infrared imagery. Remote Sens. Environ. 2015, 160, 43-55. [CrossRef]

43. Fullerton, A.H.; Torgersen, C.E.; Lawler, J.J.; Steel, E.A.; Ebersole, J.L.; Lee, S.Y. Longitudinal thermal heterogeneity in rivers and refugia for coldwater species: Effects of scale and climate change. Aquat. Sci. 2018, 80, 3. [CrossRef] [PubMed]

44. Harvey, M.C.; Hare, D.K.; Hackman, A.; Davenport, G.; Haynes, A.B.; Helton, A.; John, W.; Lane, J.; Briggs, M.A. Evaluation of Stream and Wetland Restoration Using UAS-Based Thermal Infrared Mapping. Water 2019, 11, 1568. [CrossRef]

45. US Geological Survey. USGS Water Data for the Nation: U.S. Geological Survey National Water Information System Database. 2021. Available online: https:// doi.org/10.5066/F7P55KJN (accessed on 1 October 2021).

46. Stone, J.R.; Schafer, J.P.; London, E.H.; DiGiacomo-Cohen, M.L.; Lewis, R.S.; Thompson, W. Quaternary Geologic Map of Connecticut and Long Island Sound Basin. Scientific Investigations Map 2784. 2005. Available online: https:/ / pubs.er.usgs.gov/ publication/sim2784 (accessed on 29 October 2021).

47. Harvey, M.; Briggs, M.A.; Dawson, C.B.; White, E.A.; Fosberg, D.; Haynes, A.; Moore, E. Thermal infrared and photogrammetric data collected by small unoccupied aircraft system for the evaluation of wetland restoration design at Tidmarsh Wildlife Sanctuary, Plymouth, Massachusetts, USA. U.S. Geol. Surv. Public Data Release 2019. [CrossRef]

48. Fitch, K.; Kelleher, C.; Caldwell, S.; Joyce, I. Airborne Thermal Infrared Videography of Stream Temperature from a Small Unmanned Aerial System. HPEye 2018, 32, 2616-2619. [CrossRef]

49. Barclay, J.R. Imprints of the Land: Spatial and Temporal Connections between Land Use and Water Quality. Ph.D. Thesis, University of Connecticut, Storrs, CT, USA, 2019.

50. Lapham, W.W. Use of temperature profiles beneath streams to determine rates of vertical ground-water flow and vertical hydraulic conductivity. U.S. Geol. Surv. Water-Supply Pap. 1989, 2337.

51. Wieczorek, M.E. Area- and Depth-Weighted Averages of Selected SSURGO Variables for the Conterminous United States and District of Columbia. U.S. Geol. Surv. Data Ser. 2014, 866.

52. Moore, E.M.; Jackson, K.E.; Haynes, A.B.; Harvey, M.; Helton, A.M.; Briggs, M.A. Thermal infrared images of groundwater discharge zones in the Farmington and Housatonic River watersheds (Connecticut and Massachusetts, 2019) (ver. 2.0, November 2021). U.S. Geol. Surv. Data Release 2020. [CrossRef]

53. Cole, L.J.; Stockan, J.; Helliwell, R. Managing riparian buffer strips to optimise ecosystem services: A review. Agric. Ecosyst. Environ. 2020, 296, 106891. [CrossRef]

54. O'Sullivan, A.M.; Devito, K.J.; Curry, R.A. The influence of landscape characteristics on the spatial variability of river temperatures Catena 2019, 177, 70-83. [CrossRef]

55. Sullivan, C.; Vokoun, J.; Helton, A.; Briggs, M.A.; Kurylyk, B. An ecohydrological typology for thermal refuges in streams and rivers. Ecohydrology 2021, 14, e2295. [CrossRef]

56. Hare, D.K.; Helton, A.M.; Johnson, Z.C.; Lane, J.W.; Briggs, M.A. Continental-scale analysis of shallow and deep groundwater contributions to streams. Nat. Commun. 2021, 12, 1450. [CrossRef]

57. Hammond, J.C.; Fleming, B.J. Evaluating low flow patterns, drivers and trends in the Delaware River Basin. J. Hydrol. 2021, 598, 126246. [CrossRef]

58. Odom, W.E.; Doctor, D.H.; Burke, C.E.; Cox, C.L. Using high-resolution lidar and deep learning models to generate minimum thickness maps of surficial sediments. In Proceedings of the Geological Society of America Abstracts with Programs, Portland, OR, USA, 10-13 October 2021; p. 53. 